\title{
Synthesis of $\boldsymbol{\beta}$-Tubulin, Actin, and Other Proteins in Axons of Sympathetic Neurons in Compartmented Cultures
}

\author{
Hubert Eng, Karen Lund, and Robert B. Campenot \\ Department of Cell Biology, University of Alberta, Edmonton, Alberta, T6G 2H7 Canada
}

The proteins needed for growth and maintenance of the axon are generally believed to be synthesized in the cell bodies and delivered to the axons by anterograde transport. However, recent reports suggest that some proteins can also be synthesized within axons. We used $\left[{ }^{35}\right.$ S]methionine metabolic labeling to investigate axonal protein synthesis in compartmented cultures of sympathetic neurons from newborn rats. Incubation of distal axons for $4 \mathrm{hr}$ with [ ${ }^{35}$ S]methionine resulted in a highly specific pattern of labeled axonal proteins on SDS-PAGE, with 4 prominent bands in the $43-55 \mathrm{kDa}$ range. The labeled proteins in axons were not synthesized in the cell bodies, because they were also produced by axons after the cell bodies had been removed. Two of the proteins were identified by immunoprecipitation as actin and $\beta$-tubulin. Axons synthesized $<1 \%$ of the actin and tubulin synthesized in the cell bodies and trans- ported into the axons, and $75-85 \%$ inhibition of axonal protein synthesis by cycloheximide and puromycin failed to inhibit axonal elongation. Nonetheless, the specific production by axons of the major proteins of the axonal cytoskeleton suggests that axonal protein synthesis arises from specific mechanisms and likely has biological significance. One hypothetical scenario involves neurons with long axons in vivo in which losses from turnover during axonal transport may limit the availability of cell body synthesized proteins to the distal axons. In this case, a significant fraction of axonal proteins might be supplied by axonal synthesis, which could, therefore, play important roles in axonal maintenance, regeneration, and sprouting.

Key words: actin; tubulin; axonal protein synthesis; compartmented cultures; [ ${ }^{35}$ S]methionine metabolic labeling; axon growth
It has been widely believed that lipids and proteins cannot be synthesized within axons but must be synthesized in neuronal cell bodies and transported along the axons. However, results of experiments with compartmented cultures of rat sympathetic neurons have demonstrated local synthesis of phospholipids within axons (Vance et al., 1991). In fact, $50 \%$ or more of the phosphatidylcholine content of axons originates from axonal synthesis from choline, and block of axonal synthesis severely inhibits axon growth (Posse de Chaves et al., 1995).

Indirect evidence for axonal protein synthesis has accumulated. The initial findings of RNA (Lasek et al., 1973) and poly(A) mRNA (Capano et al., 1987) in axons led to the identification of several mRNA molecules encoding cytoskeletal and other proteins (Table 1). The presence of ribosomes (Koenig, 1979; Giuditta et al., 1980; Koenig and Martin, 1996) and polyribosomes (Giuditta et al., 1991) in axons has added further support to the theory that axons have the capability to synthesize proteins. Indirect evidence of axonal protein synthesis was obtained in isolated growth cones from snail axons in which incorporation of $\left[{ }^{3} \mathrm{H}\right]$ leucine was blocked by $70 \%$ using anisomycin (Davis et al., 1992). Direct evidence of axonal protein synthesis has been presented by Koenig (1989, 1991), who reported labeling of a number of protein bands on SDS-PAGE of extracts from isolated

\footnotetext{
Received July 13, 1998; revised Sept. 28, 1998; accepted Oct. 12, 1998.

This research was supported by the Medical Research Council of Canada Grant 51-11056. H.E. is a recipient of salary support from the Alberta Neurotrauma Fund. R.B.C. is an Alberta Heritage Foundation Medical Scientist. We thank G. Martin for excellent technical assistance and E. Posse de Chaves for critical reading of this manuscript.

Correspondence should be addressed to Dr. Robert B. Campenot, Department of Cell Biology, G-22 Medical Sciences Building, University of Alberta, Edmonton, Alberta, T6G 2H7 Canada.

Copyright (C) 1998 Society for Neuroscience $\quad 0270-6474 / 98 / 180001-09 \$ 05.00 / 0$
}

axons of adult goldfish and rat neurons that had been incubated in $\left[{ }^{35} \mathrm{~S}\right]$ methionine $\left(\left[{ }^{35} \mathrm{~S}\right] \mathrm{met}\right)$. Cycloheximide inhibited protein synthesis by $80 \%$ in goldfish retinal axons (Koenig and Adams, 1982).

Previous studies have not provided direct identification of any proteins made by axons, presumably because of the difficulties of obtaining sufficient quantities of pure axons for analysis, nor have previous studies provided information about how much axonal protein is made locally and how much is transported from the cell bodies. As well, the role of axonal protein synthesis in axonal growth or other biological functions has not been analyzed.

To investigate these issues, we used compartmented cultures of primary rat sympathetic neurons, which separate distal axons and their growth cones from cell bodies and proximal axons (Campenot, 1977, 1992, 1997). We found proteins are synthesized in distal axons, amounting to $\sim 0.5 \%$ of the protein synthesized by the entirety of the neurons. Distal axons synthesized proteins even after removal of the cell bodies. Two of the proteins synthesized by axons were identified as actin and $\beta$-tubulin. Less than $1 \%$ of actin and tubulin was synthesized in distal axons compared with that made in the cell bodies. Inhibition of protein synthesis in distal axons by cycloheximide and puromycin did not inhibit axon growth, suggesting that, unlike the case for lipids, protein synthesis in distal axons is not an absolute requirement for axon growth under the present experimental conditions.

\section{MATERIALS AND METHODS}

Reagents and antibodies. Cycloheximide and puromycin were obtained from Sigma (St. Louis, MO). Antibodies to the following cytoskeletal proteins were used: actin (clone C4; Boehringer Mannheim, Laval, Quebec, Canada), $\beta$-actin (clone AC-15; Sigma), and $\beta$-tubulin (clone Tub 2.1; Sigma). All other chemicals were reagent grade.

Neuronal culture. Compartmented cultures of sympathetic neurons 


\begin{tabular}{lll}
\hline \multicolumn{2}{l}{ Table 1. Presence of mRNA in axons } \\
mRNA for & Animal & Reference \\
\hline$\beta$-actin & rat brain & Bassell et al., 1998 \\
$\beta$-actin & chick neurons & $\begin{array}{l}\text { Olink-Coux and } \\
\text { Hollenbeck, 1996 }\end{array}$ \\
$\beta$-actin & squid axon & Kaplan et al., 1992 \\
$\beta$-tubulin & squid axon & Kaplan et al., 1992 \\
neurofilament & gold fish brain & Weiner et al., 1996 \\
neurofilament & squid axon & Crispino et al., 1993 \\
tau & rat brain & Litman et al., 1993 \\
kinesin & squid axon & Gioio et al., 1994 \\
neuropeptides & rat brain & Mohr et al., 1991 \\
enolase & squid axon & Chun et al., 1995 \\
pA6 & squid axon & Chun et al., 1997 \\
\hline
\end{tabular}

from superior cervical ganglia of newborn Sprague Dawley rats were cultured as described previously (Campenot, 1992, 1997). Briefly, Teflon dividers (Tyler Research Instruments, Edmonton, Alberta, Canada) were used to partition the culture into one central and two side compartments (Fig. 1). Cell bodies are retained in the center compartment, and axons extend into the side compartments. Neurons were plated into the center compartments with medium supplemented with $10 \mathrm{ng} / \mathrm{ml} 2.5 \mathrm{~S}$ nerve growth factor (NGF) (Cedarlane, Hornby, Ontario, Canada) and $2.5 \%$ rat serum, with $10 \mu \mathrm{M}$ cytosine arabinoside added to remove non-neuronal cells. NGF was provided at $100 \mathrm{ng} / \mathrm{ml}$ in the side compartments. After $6 \mathrm{~d}$ in culture, NGF and cytosine arabinoside were discontinued in the center compartments. From that time onward, cultures were maintained with $2.5 \%$ rat serum in the center compartments and 100 $\mathrm{ng} / \mathrm{ml} \mathrm{NGF}$ in the side compartments. Cultures were used in experiments 11-15 d after plating. In some experiments, the cell bodies in the center compartments were removed immediately before the incubation by a stream of distilled water delivered through a $3 \mathrm{ml}$ syringe with a 22 gauge needle.

${ }^{35}$ S $]$ Methionine metabolic labeling. Labeling medium was prepared by adding $\left[{ }^{35} \mathrm{~S}\right] \mathrm{met}$ (ICN Biochemicals, Montreal, Quebec, Canada) at a specific activity of $250 \mu \mathrm{Ci} / \mathrm{ml}$ to culture medium lacking methionine. To metabolically label proteins produced in cell bodies, labeling medium containing $2.5 \%$ rat serum was added only to the center compartments, whereas side compartments were provided with ordinary culture medium containing $100 \mathrm{ng} / \mathrm{ml}$ NGF. To label proteins produced in distal axons, labeling medium containing $100 \mathrm{ng} / \mathrm{ml} \mathrm{NGF}$ was added only to the left and right compartments, whereas center compartments were provided with ordinary culture medium containing $2.5 \%$ rat serum. Cultures were incubated for $4 \mathrm{hr}$ and then lysed and extracted as below.

Protein analysis. After rinsing three times in TBS $(20 \mathrm{~mm}$ Tris and 0.14 $\mathrm{M} \mathrm{NaCl}, \mathrm{pH}$ 7.2), the neuronal material was harvested into lysis buffer (0.5\% SDS, $1 \mathrm{~mm}$ EDTA, and $10 \mathrm{~mm}$ Tris- $\mathrm{HCl}, \mathrm{pH} 7.5)$, similar to the previously described procedure (Campenot et al., 1996). Center compartments were harvested separately from left and right compartments. Bovine serum albumin (10 $\mu \mathrm{g} / \mathrm{ml}$ final) was added to the lysate, and the proteins were precipitated by adding trichloroacetic acid to a final volume of $10 \% \mathrm{v} / \mathrm{v}$ for $1 \mathrm{hr}$ at $4^{\circ} \mathrm{C}$. The precipitate was then collected by centrifugation at $10,000 \times g$ for $20 \mathrm{~min}$, and the pellet was resuspended in $30 \mu \mathrm{l}$ of SDS sample buffer. After raising the $\mathrm{pH}$ of the samples with $1 \mathrm{M}$ Tris, they were boiled for $10 \mathrm{~min}$ and loaded on a $10 \%$ SDS polyacrylamide gel. Lanes contained extracts of 4-10 cultures as indicated in Results. After separation, proteins were electrophoretically transferred in a semidry unit (Hoefer Scientific, San Francisco, CA) to Hyperbond nitrocellulose (Amersham, Oakville, Ontario, Canada) and exposed to a phosphorimager plate. Plates were read in the BAS 1000 Bio-Imaging Analyzer (Fuji Photo Film Co., Ltd., Tokyo, Japan) after exposing for $4 \mathrm{~d}$, unless otherwise stated, and analyzed using MacBAS software (Fujix, Tokyo, Japan).

Inhibition of protein synthesis. Stock solutions of cycloheximide (100 $\mu \mathrm{g} / \mathrm{ml}, 35 \mathrm{~mm})$ and puromycin $(120 \mu \mathrm{g} / \mathrm{ml}, 40 \mathrm{~mm})$ in TBS were diluted 1:100 into culture medium. The medium in the side compartments were replaced with medium containing one of the inhibitors or plain medium as control. After a preincubation of $2 \mathrm{hr}$, the cells were metabolically labeled and then processed as described above.
A

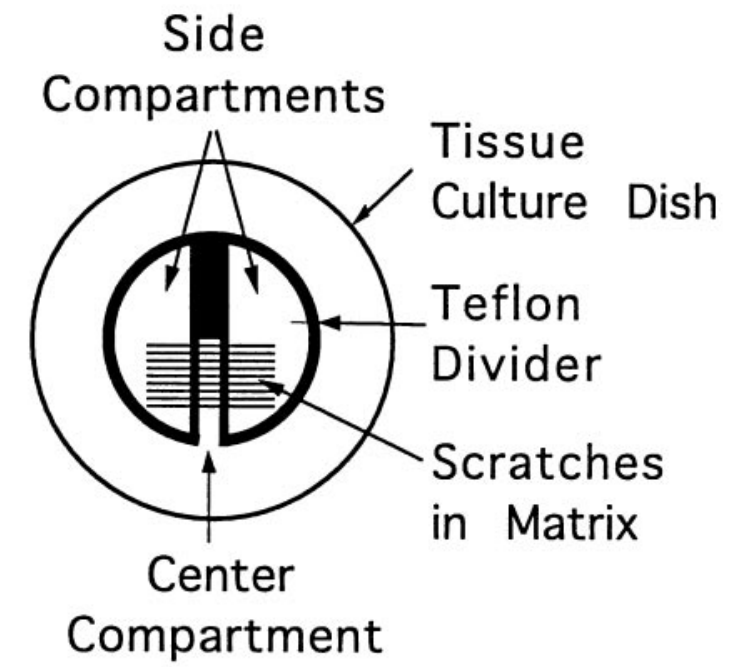

B

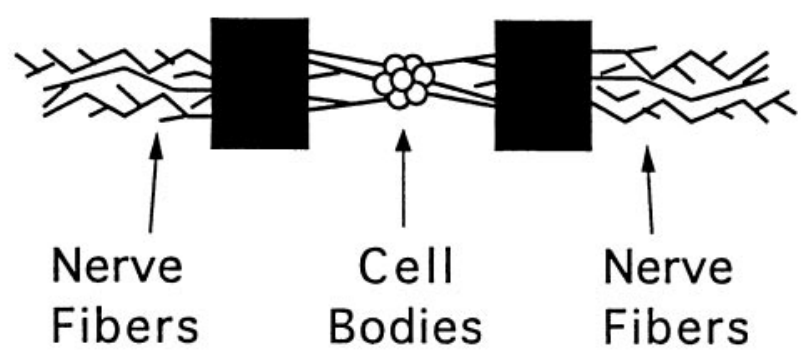

Figure 1. Schematic diagram of a compartmented culture. A, A Teflon divider provides a barrier that divides the culture dish into one central compartment and two side compartments. $B$, An enlargement of a single track shows the cell bodies and proximal axons restricted to the center compartment, whereas the distal axons cross under the barrier and extend into the side compartments.

Immunoprecipitation. Immunoprecipitation of proteins was performed similar to that described previously (Campenot et al., 1996). In brief, axons in the left and right compartments were metabolically labeled as above and then lysed in $0.5 \%$ deoxycholate, $0.1 \%$ SDS, and $50 \mathrm{~mm}$ Tris-HCl, $\mathrm{pH}$ 7.5. The pooled lysate from the side compartments of 4-10 cultures was passed through a 20 gauge hypodermic needle several times, centrifuged at $10,000 \times g$ for $10 \mathrm{~min}$ to remove cellular debris, and either frozen or used immediately. After an overnight incubation at $4^{\circ} \mathrm{C}$ in primary antibody, $30 \mu \mathrm{l}$ of Protein A/G coupled Sepharose beads (Santa Cruz Biotechnology, Santa Cruz, CA) was added and incubated for $2 \mathrm{hr}$ at $4^{\circ} \mathrm{C}$ with end-over-end mixing. The beads were collected by centrifugation and washed three times in $0.5 \%$ Tween $20-$ PBS. To dissociate the bound protein from the beads, the sample was boiled for $10 \mathrm{~min}$ in SDS sample buffer. After a final centrifugation, the supernatant was collected and separated on a $10 \%$ SDS polyacrylamide gel, transferred to nitrocellulose as above, and exposed to the phosphorimager plate for $7 \mathrm{~d}$.

Axonal growth and protein synthesis inhibitors. Cycloheximide ( $35 \mathrm{~mm})$ and puromycin $(40 \mathrm{~mm})$ were prepared as above and diluted 1:100 in culture medium. Medium in the right compartment was replaced with medium containing either cycloheximide or puromycin, and medium in the left compartment was replaced with plain medium as control. The distance the axons extended along the tracks was measured from the edge of the silicone grease, where the axons emerged into the side compartment, to the most distal axon tip as described previously (Campenot, 1992). These measurements were made using a Nikon Dia- 

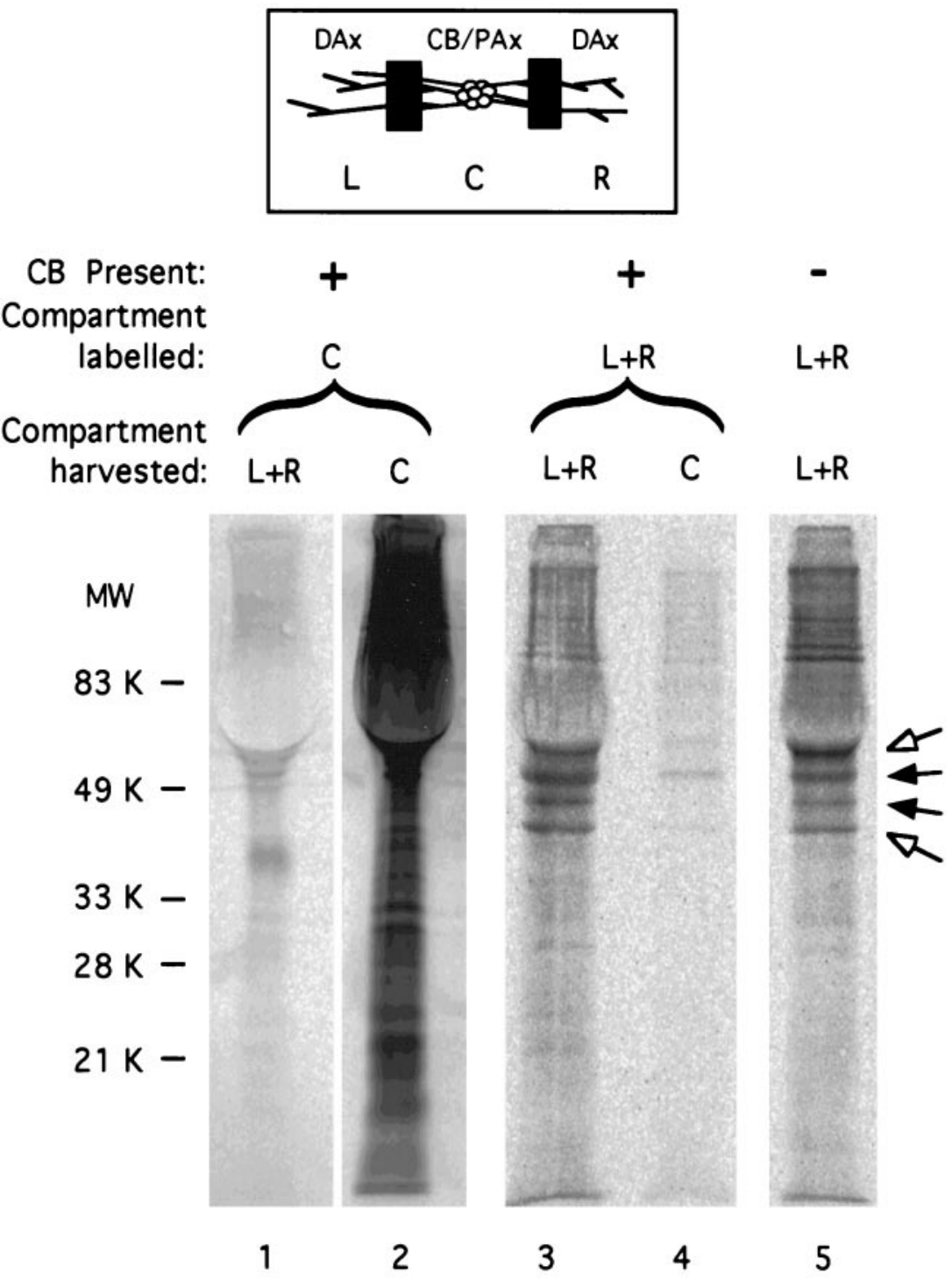

Figure 2. Comparison of the profiles of proteins labeled by incubation with $\left[{ }^{35} \mathrm{~S}\right] \mathrm{met}$ in left and right compartments or center compartments. Lanes 1,2, The center compartments of cultures were incubated for $4 \mathrm{hr}$ with 250 $\mu \mathrm{Ci} / \mathrm{ml}\left[{ }^{35} \mathrm{~S}\right] \mathrm{met}$ before harvesting the left and right $(L+R)$ and center compartments $(C)$. Extracts were analyzed by SDS-PAGE as described in Materials and Methods. Protein from three cultures was loaded on each lane. Lanes 3, 4, To assess the possibility of protein synthesis in distal axons, left and right compartments of cultures were incubated with $\left[{ }^{35} \mathrm{~S}\right] \mathrm{met}$ for $4 \mathrm{hr}$, and the cultures were analyzed. Protein from 10 cultures was loaded on each lane. Lane 5, To determine whether the labeled proteins detected in axons incubated with $\left[{ }^{35} \mathrm{~S}\right] \mathrm{met}$ were transported there after synthesis in the cell bodies, the cell bodies were removed from cultures immediately before labeling the distal axons for $4 \mathrm{hr}$ with $\left[{ }^{35} \mathrm{~S}\right] \mathrm{met}$. Protein from 10 cultures was loaded on this lane. phot microscope with phase-contrast optics fitted with an MD2 microscope digitizer (Minnesota Datametrics, Minneapolis, MN) to track stage position $( \pm 5 \mu \mathrm{m})$. In each culture, measurements were made from five tracks in each of the side compartments immediately after adding the drugs and again after 6 and $30 \mathrm{hr}$. The data for each time point were collectively analyzed to obtain the mean $\pm \mathrm{SE}$ in a given time period.

\section{RESULTS}

\section{Direct labeling of cell bodies and distal axons with $\left[{ }^{35} \mathrm{~S}\right]$ methionine produced different patterns and distributions of labeled proteins}

We used compartmented cultures to determine whether proteins are synthesized by axons of rat sympathetic neurons. First, we compared the SDS-PAGE phosphorimage profiles of cultures incubated with $\left[{ }^{35} \mathrm{~S}\right] \mathrm{met}$ supplied to center compartments to the profiles from cultures with $\left[{ }^{35} \mathrm{~S}\right]$ met supplied to axons in left and right compartments. Cultures were incubated with $250 \mu \mathrm{Ci} / \mathrm{ml}$ $\left[{ }^{35} \mathrm{~S}\right]$ met for $4 \mathrm{hr}$, and culture extracts were analyzed by SDSPAGE and phosphorimaging as described in Materials and Methods.

As expected, incubation of the cell body compartments with $\left[{ }^{35} \mathrm{~S}\right] \mathrm{met}$ resulted in the appearance of many radiolabeled proteins (Fig. 2, lane 2). Relatively faint labeling of a subset of bands appeared in the distal axons (Fig. 2, lane 1), presumably arising from anterograde axonal transport of proteins synthesized in the cell bodies. Incubation of the distal axons with $\left[{ }^{35} \mathrm{~S}\right] \mathrm{met}$ in left and right compartments resulted in the appearance of labeled proteins in the distal axons (Fig. 2, lane 3). There were fewer labeled bands than observed in directly labeled cell body compartments. Four prominent bands were present in distal axons at apparent molecular weights of $\sim 55,51,47$, and $43 \mathrm{kDa}$. The bands at 55 and $43 \mathrm{kDa}$ (Fig. 2, open arrows) correspond in molecular weight to actin and tubulin (see below).

Incubation of distal axons with $\left[{ }^{35} \mathrm{~S}\right]$ met resulted in a much smaller amount of radiolabeled proteins in the neurons than resulted from incubation of the cell bodies-proximal axons. This difference is larger than is apparent in Figure 2, because three cultures were loaded per lane for the cell body-proximal axon incubations, whereas 10 cultures were loaded per lane for the distal axon incubations to produce a reliable signal. Phosphorimager analysis of the intensity profiles in Figure 2 revealed that, on a per culture basis, incubation of distal axons resulted in only $0.5 \%$ of the radioactivity in total neuronal protein (lanes 3,4 ) that was produced when cell bodies-proximal axons were incubated 
(lanes 1, 2). Because incubation of distal axons produced prominent labeled bands between 43 and $55 \mathrm{kDa}$, we compared protein labeling in this range. For these proteins, incubation of distal axons produced $0.8 \%$ of the radioactivity that was produced by incubation of the cell bodies-proximal axons. Analysis of the presumed actin and tubulin bands indicated that incubation of distal axons resulted in $0.7 \%$ of the radioactivity that was produced by incubation of the cell bodies-proximal axons.

Phosphorimager scans from three separate experiments also indicated that, after incubation of distal axons, $\sim 82 \pm 4 \% \mathrm{SD}$ of the radiolabeled protein was found in the distal axons, whereas $18 \pm 5 \%$ SD was found in the cell body compartments (Fig. 2, compare lanes 3,4). These labeled proteins displayed a similar pattern to that observed in the distal axons.

\section{Proteins labeled by $\left[{ }^{35}\right.$ S $]$ methionine applied to distal axons are synthesized within the distal axons}

There are two hypotheses that could account for the appearance of labeled proteins in distal axons after direct incubation in $\left[{ }^{35} \mathrm{~S}\right]$ met. The first possible scenario is that $\left[{ }^{35} \mathrm{~S}\right]$ met entered the distal axons, traveled to the cell bodies either by diffusion or retrograde axonal transport, was incorporated into proteins synthesized in the cell bodies, and finally was anterogradely transported into the distal axons. It is difficult to see how proteins produced in this way could produce greater labeling in the distal axons (Fig. 2, lane 3) than in the cell bodies (lane 4) during the 4 hr incubation, because very little protein directly labeled in the cell bodies (lane 2) was transported into distal axons (lane 1) during this time. Also, it is hard to explain in this scenario why supplying $\left[{ }^{35} \mathrm{~S}\right]$ met to the cell bodies via the distal axons would result in a different banding pattern of labeled proteins than is observed when $\left[{ }^{35} \mathrm{~S}\right]$ met is supplied directly to the cell bodies. Thus, the data presented so far are not consistent with the exclusive synthesis of proteins in the cell body compartment.

The alternative hypothesis is that $\left[{ }^{35} \mathrm{~S}\right]$ met entered the distal axons and was incorporated into proteins synthesized within the distal axons. This scenario would explain why direct incubation of distal axons results in far greater protein labeling in distal axons than in cell bodies. If it is further hypothesized that axons only synthesize a subset of the proteins produced in cell bodies, the difference in banding pattern can be easily explained.

To directly determine whether the radiolabeled proteins detected in the axon compartment were synthesized by axons, we removed the cell bodies from the center compartments of cultures immediately before the $4 \mathrm{hr}$ incubation of the distal axons with $\left[{ }^{35} \mathrm{~S}\right] \mathrm{met}$. Previous results have shown that axons isolated in this manner retain a normal rate of phosphatidylcholine synthesis for at least $5 \mathrm{hr}$ (Posse de Chaves et al., 1995). SDS-PAGE of extracts of distal axons from 10 cultures (Fig. 2, lane 5) revealed protein bands of similar pattern and intensity as the radiolabeled proteins detected in the distal axons of intact neurons (Fig. 2, lane 3). We conclude that the labeled proteins arising in distal axons from direct incubation in $\left[{ }^{35} \mathrm{~S}\right]$ met were produced by protein synthesis occurring within the distal axons.

\section{Inhibition of axonal protein synthesis by cycloheximide and puromycin}

To determine whether protein synthesis inhibitors could be useful tools to investigate the biological function of axonal protein synthesis, the distal axon compartments were preincubated for 2 hr with culture medium containing either cycloheximide (100 $\mu \mathrm{g} / \mathrm{ml})$, puromycin $(120 \mu \mathrm{g} / \mathrm{ml})$, or no drug as control. Then, the distal compartment medium was replaced with $\left[{ }^{35} \mathrm{~S}\right]$ met labeling medium containing the inhibitor or no inhibitor as appropriate, and the cultures were incubated for an additional $4 \mathrm{hr}$. Proteins were harvested and analyzed by SDS-PAGE as described in Materials and Methods. Figure $3 A$ shows a representative phosphorimage of three experiments that were performed, and Figure $3 B$ shows quantitation of these lanes expressed relative to the control. Quantitation of the lanes from all three experiments revealed that cycloheximide inhibited protein synthesis by $\sim 76 \pm$ $9 \% \mathrm{SD}$ and puromycin by $\sim 84 \pm 4 \% \mathrm{SD}$.

Direct $\left[{ }^{35} \mathrm{~S}\right] \mathrm{met}$ incubation of distal axons resulted in the appearance of some labeled proteins in the cell body compartments (Fig. 3C, lane 1). In this experiment, the cell bodies contained $23 \%$ of the total label. The labeled proteins displayed a similar pattern to that observed in the distal axons (Fig. $3 A$, lane 1 ), and they were inhibited by cycloheximide and puromycin supplied to distal axons (lanes 2 and 3), suggesting that these labeled proteins were synthesized in the distal axons and retrogradely transported into the cell body compartments (see Discussion).

Neither $100 \mu \mathrm{g} / \mathrm{ml}$ cycloheximide nor $120 \mu \mathrm{g} / \mathrm{ml}$ puromycin applied to distal axons completely abolished the appearance of labeled proteins in the distal axons. In particular, the band at 47 $\mathrm{kDa}$ appeared least sensitive to the inhibitors. To exclude the unlikely possibility that production of proteins in the cell bodies not exposed to the inhibitors could somehow have contributed to the residual labeled proteins observed in axons, we repeated the experiment in cultures in which the cell bodies had been removed. Similar results were obtained in the absence of cell bodies (Fig. 4 ), with protein synthesis inhibited by $68 \%$ by cycloheximide, $80 \%$ by puromycin, and with the band at $47 \mathrm{kDa}$ least affected by both inhibitors.

\section{Synthesis of actin and $\boldsymbol{\beta}$-tubulin in axons}

Because one of the major bands synthesized in distal axons corresponds in molecular weight to actin at $55 \mathrm{kDa}$ and another corresponds to tubulin at $43 \mathrm{kDa}$ (Fig. 2, lane 5), we hypothesized that actin and tubulin are likely to be among the proteins synthesized by distal axons. We tested this by immunoprecipitation using antibodies to actin, $\beta$-actin, and $\beta$-tubulin. To ensure that all metabolically labeled proteins were produced only in the axons, the cell bodies were removed before labeling. The axons were incubated in $\left[{ }^{35} \mathrm{~S}\right]$ met labeling medium for $4 \mathrm{hr}$ and then lysed and incubated with either anti-actin, anti- $\beta$-actin, or anti$\beta$-tubulin antibodies. Any immunoprecipitated proteins were detected by SDS-PAGE separation and phosphorimaging as described in Materials and Methods.

Anti-actin antibodies (Fig. 5, lane 1) precipitated labeled actin (43 kDa, filled arrow) and coprecipitated one major labeled band at $56 \mathrm{kDa}$ (open arrow), as well as several other minor bands. Although mRNA for $\beta$-actin has been reported in rat axons (Bassell et al., 1998) and we were able to immunoprecipitate labeled $\beta$-actin from labeled whole neurons, we detected no labeled $\beta$-actin in immunoprecipitates of labeled distal axons (data not shown). Anti- $\beta$-tubulin antibodies (Fig. 5, lane 2) precipitated $\beta$-tubulin ( $55 \mathrm{kDa}$, filled arrow), as well as four other bands (open arrows) of molecular weight of 85, 75, 14, and $12 \mathrm{kDa}$. 

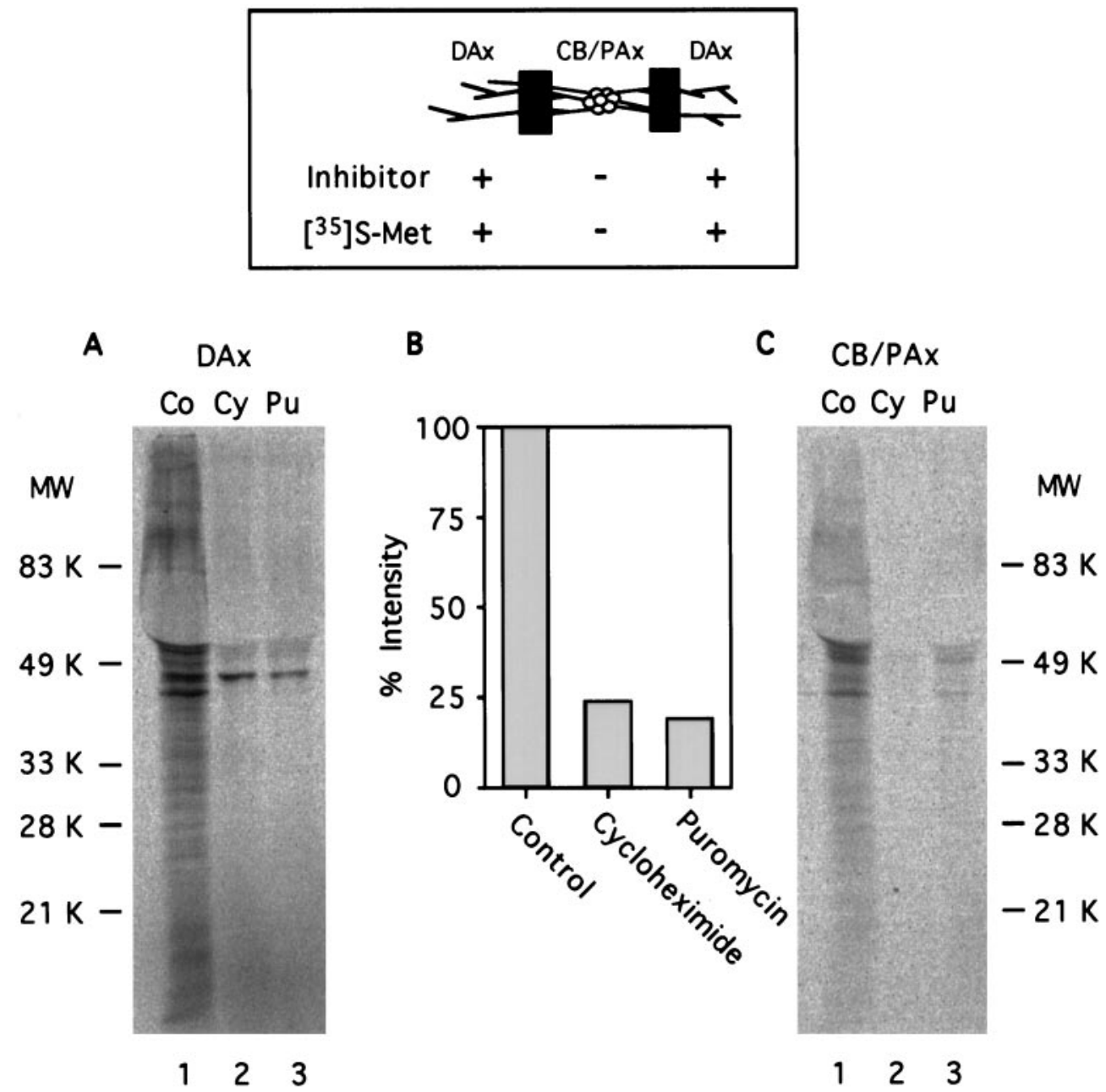

Figure 3. Inhibition of axonal protein synthesis. Cultures were preincubated $2 \mathrm{hr}$ with culture medium in the distal axon compartments containing either cycloheximide $(100 \mu \mathrm{g} / \mathrm{ml} ; C y)$, puromycin $(120 \mu \mathrm{g} / \mathrm{ml} ; \mathrm{Pu})$, or no drug as control $(\mathrm{Co})$. Then, the distal compartment medium was replaced with [ $\left.{ }^{35} \mathrm{~S}\right] \mathrm{met}$ labeling medium containing the inhibitor or no inhibitor as appropriate, and the cultures were incubated for 4 hr. Proteins were harvested and analyzed by SDS-PAGE as described in Materials and Methods. Protein from six cultures was loaded on each lane. $A$, Lanes from the distal axons $(D A x)$. $B$, Density of the individual lanes from $A$ quantitated by phosphorimaging and expressed as a percentage of the control lane. $C$, Lanes from the cell bodies and proximal axons $(C B / P A x)$.

We conclude that actin and $\beta$-tubulin are among the proteins synthesized by distal axons of cultured rat sympathetic neurons.

\section{Effect of inhibition of axonal protein synthesis on axon extension}

Although the above data provides evidence that axons can synthesize proteins, there is no indication of the function of axonal protein synthesis. It has been postulated that axonal protein synthesis may supply cytoskeletal proteins needed for growth cone motility (Bassell et al., 1998). To test for this, we exposed distal axons in intact cultures to concentrations of cycloheximide $(100 \mu \mathrm{g} / \mathrm{ml})$ and puromycin $(120 \mu \mathrm{g} / \mathrm{ml})$, which inhibited protein synthesis. We measured the distance that the axons had extended along the tracks 6 and $30 \mathrm{hr}$ after adding the drugs. Neither cycloheximide (Fig. 6A) nor puromycin (Fig. 6B) reduced the rate of axon advancement along the tracks, even after $30 \mathrm{hr}$ of incubation. As a control, the same concentration of cycloheximide or puromycin was directly applied to the cell bodies, and within $24 \mathrm{hr}$ the axons had detached from the surface and were no longer viable.

\section{DISCUSSION}

Protein synthesis in axons of sympathetic neurons

Direct application of $\left[{ }^{35}\right.$ S $]$ met to distal axons of rat sympathetic neurons in compartmented cultures produced a characteristic pattern of labeled axonal proteins, with four prominent bands in the 43-55 kDa range. Moreover, the pattern and magnitude of labeled axonal proteins was unaltered when axons were isolated by removal of the cell bodies before labeling, directly demonstrating that the labeled proteins were synthesized by the distal axons. Cycloheximide and puromycin applied to axons inhibited the appearance of labeled proteins in axons by $\sim 75$ and $85 \%$, respectively, consistent with an axonal site of production and with previous results in other systems (see introductory remarks). The profile of radiolabeled proteins observed by SDS-PAGE in the present study is similar to the profile of proteins synthesized in isolated axons of adult goldfish and rats (Koenig, 1991). Thus, it appears that the ability of axons to synthesize proteins is not restricted to developing axons but persists into adulthood and may be a widely conserved phenomenon in the animal kingdom. 
Figure 4. Inhibition of axonal protein synthesis by direct application of cycloheximide and puromycin in isolated axons. The center compartments were washed with distilled water to remove the cell bodies before labeling. Control axons (Co) were not treated with drugs. Application of cycloheximide $(C y)$ and puromycin $(P u)$, labeling of axons, and analysis were as in Figure 3. Protein from six cultures was loaded on each lane.

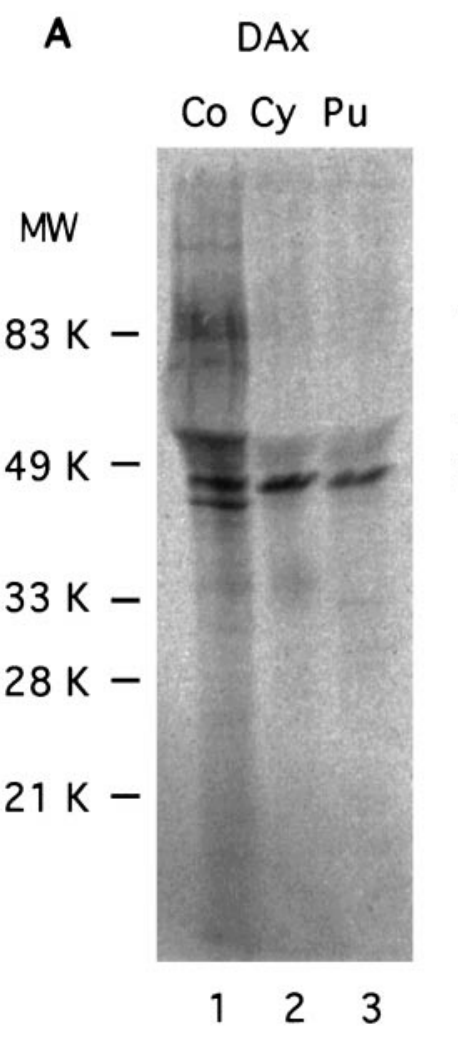

B

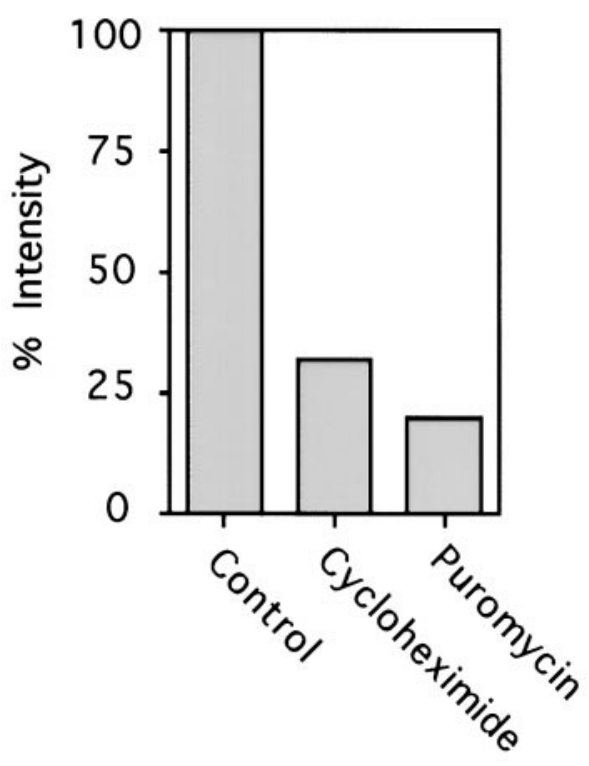

The present results are an important addition to the mounting evidence (see introductory remarks) indicating that some proteins can be synthesized within axons.

After a $4 \mathrm{hr}$ incubation of distal axons in $\left[{ }^{35} \mathrm{~S}\right] \mathrm{met}, \sim 20 \%$ of all labeled proteins were detected in the center compartments containing cell bodies and proximal axons. One possibility to account for this is that $\left[{ }^{35} \mathrm{~S}\right]$ met in the distal axons traveled retrogradely and was incorporated into proteins synthesized in the proximal axons and/or cell bodies. However, the labeled proteins from the center compartments displayed the same specific bands as the proteins produced by the distal axons, not the broad range of bands characteristic of proteins produced in the cell bodies. Therefore, it is unlikely that these proteins were synthesized in the cell bodies. As yet, we cannot exclude a possible contribution of protein synthesis within the proximal axons, although the amount of cellular material in proximal axons is small relative to the distal axons (see below), and proximal axons were not directly exposed to $\left[{ }^{35} \mathrm{~S}\right] \mathrm{met}$. Finally, proteins synthesized in distal axons may have been transported or carried along with organelle traffic into the proximal axons and cell bodies (Koenig et al., 1985; Hollenbeck and Bray, 1987).

\section{$\boldsymbol{\beta}$-Tubulin and actin are synthesized in axons}

Using immunoprecipitation of isolated axons labeled with $\left[{ }^{35} \mathrm{~S}\right]$ met, we identified the $55 \mathrm{kDa}$ protein as $\beta$-tubulin and the 43 $\mathrm{kDa}$ protein as actin. These results are consistent with the previous report of 55 and $43 \mathrm{kDa}$ radiolabeled protein bands produced by isolated axons of adult rat neurons (Koenig, 1991). We detected metabolically labeled $\beta$-actin in extracts of whole neurons, and we detected $\beta$-actin immunohistochemically in filopodia and lamellipodia of growth cones. However, we did not detect any synthesis of $\beta$-actin in metabolically labeled distal axons. Because $\beta$-actin mRNA has been found in rat axons stimulated with cAMP (Bassell et al., 1998), it is possible that such stimulation may be necessary to obtain detectable axonal synthesis.

\section{The magnitude of axonal protein synthesis}

The magnitude of protein synthesis in the distal axons was small relative to synthesis in the center compartments containing the cell bodies and proximal axons. For example, analysis of the actin and $\beta$-tubulin bands indicated that incubation of distal axons with $\left[{ }^{35} \mathrm{~S}\right]$ met resulted in $0.7 \%$ of the radioactivity that was produced by incubation of the cell bodies-proximal axons. These values are 


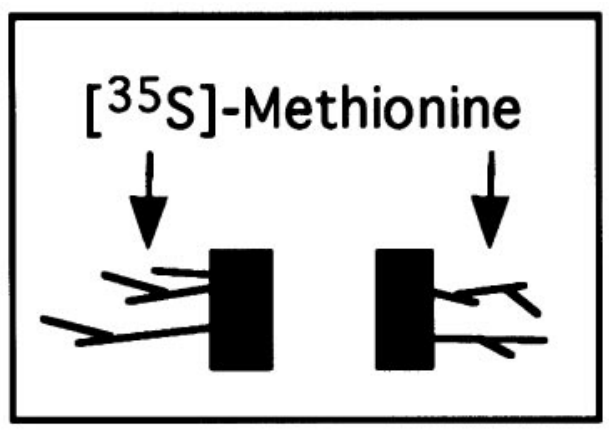

\section{Immunoprecipitation}

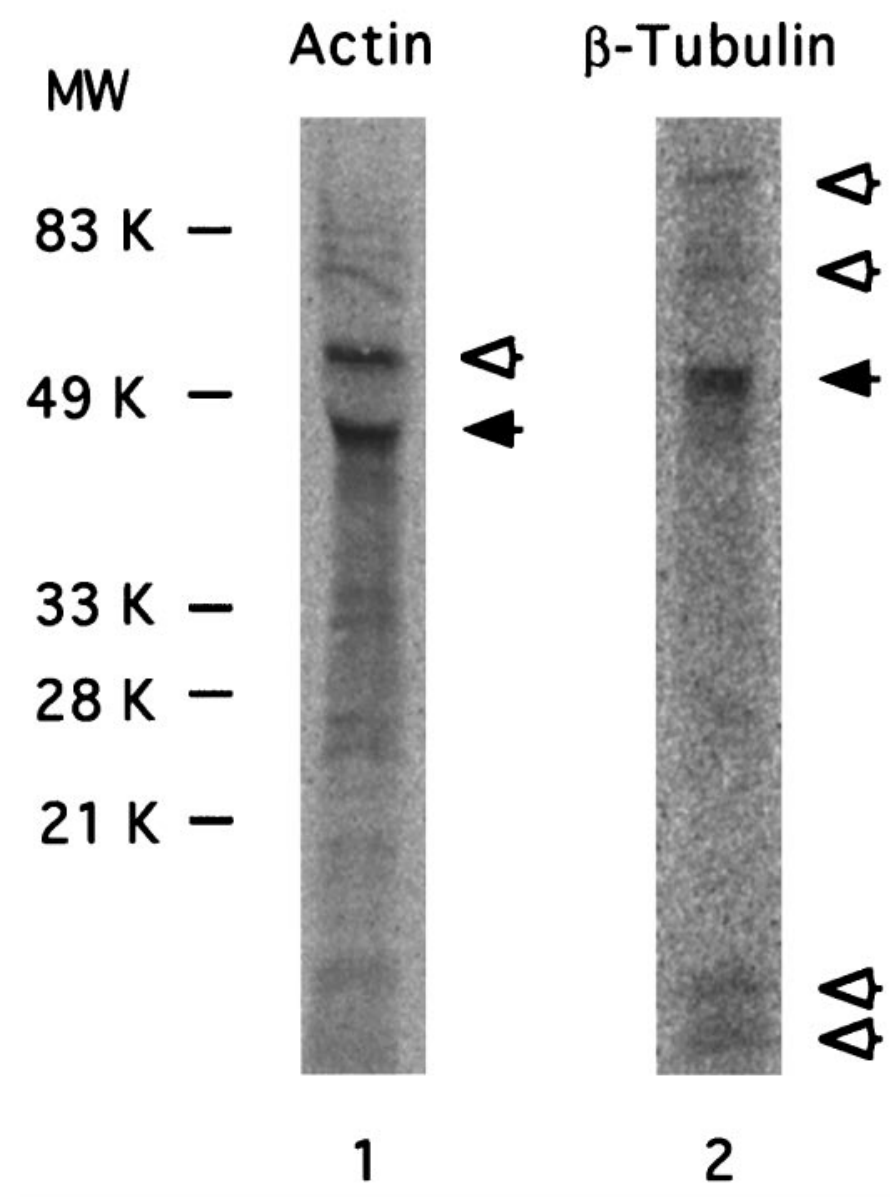

Figure 5. Immunoprecipitation of actin and $\beta$-tubulin synthesized in distal axons. After removal of the cell bodies, axons were incubated in $\left[{ }^{35} \mathrm{~S}\right]$ met for $4 \mathrm{hr}$. Cell lysates from six cultures were immunoprecipitated with either anti-actin or anti- $\beta$-tubulin antibodies as described in Materials and Methods. Immunoprecipitated proteins were analyzed by SDSPAGE and phosphorimaging. Anti-actin antibodies precipitated actin at $43 \mathrm{kDa}$ ( filled arrow) and coprecipitated one major band at $56 \mathrm{kDa}$ (open arrow), as well as several other minor bands of varying molecular weight. Anti- $\beta$-tubulin antibodies precipitated $\beta$-tubulin ( $55 \mathrm{kDa}$, filled arrow), as well as four other bands (open arrows) of molecular weight 85, 75, 14, and $12 \mathrm{kDa}$.

for the labeled actin and $\beta$-tubulin in the whole neuron and not just the region that was directly exposed to $\left[{ }^{35} \mathrm{~S}\right] \mathrm{met}$, so proteins made in distal axons and transported to the cell bodies-proximal axons are included in axonal production. These values cannot be strictly equated to the amount of these proteins that was synthesized, because cell body and axonal methionine pools could be different, resulting in different dilutions of the $\left[{ }^{35} \mathrm{~S}\right] \mathrm{met}$ and, therefore, different specific activities of the newly synthesized proteins. However, if we tentatively assume that the cell body and axonal methionine pools have comparable concentrations and availability to protein synthesis, the result is that $<1 \%$ of the actin and $\beta$-tubulin produced by the neurons is synthesized in their axons.

In this analysis, we did not consider protein synthesis within the proximal axons. The proximal axons in these cultures spanned the $1.5 \mathrm{~mm}$ center compartment, and their growth was arrested after $6 \mathrm{~d}$ in culture by withdrawal of NGF. The distal axons were exposed to NGF during the entire culture period and extended $>5 \mathrm{~mm}$ into distal compartments. Under these conditions, the density of distal axons is typically much greater than the density of proximal axons (Campenot, 1982). Thus, any proteins synthesized by proximal axons would be less than the proteins synthesized by the distal axons and far less than the proteins synthesized by the cell bodies. In conclusion, it appears certain that only a tiny fraction of the neuronal production of tubulin, actin, and other proteins occurred in the distal axons in the present experiments.

\section{Biological significance}

These experiments directly demonstrate the axonal synthesis of a subset of proteins, including actin and $\beta$-tubulin. Although the observed quantities were small, the specificity suggests that axonal protein synthesis is not an epiphenomenon arising from imperfect retention of the protein synthetic machinery in the cell bodies. Rather, axonal protein synthesis appears to arise from specific mechanisms, perhaps by trafficking specific mRNAs into the axons.

In the case of tubulin, previous work with compartmented cultures of rat sympathetic neurons has shown that $90 \%$ of newly synthesized tubulin in the cell bodies is transported into the distal axons within 2-3 d, traveling at a velocity of $\sim 4 \mathrm{~mm} / \mathrm{d}$ (Campenot et al., 1996). Because axons elongate at $\sim 1 \mathrm{~mm} / \mathrm{d}$, the $11-$ to 15 -d-old cultures used in these experiments would require only 3-4 d to transport tubulin from the cell bodies to the most distant growth cones. This is well within the half-life of tubulin in this system. Thus, in the present experiments, the distal axons obtained the majority of their tubulin by axonal transport from the cell bodies. This is likely true for actin and possibly all other proteins synthesized by axons in these experiments. Therefore, it is not surprising that block of axonal protein synthesis with cycloheximide or puromycin did not block axon growth. These results do not support the suggestion that growth cones require a supply of locally synthesized actin to function (Bassell et al., 1998).

Our inability to inhibit axon growth using protein synthesis inhibitors contrasts with investigations of axonal phospholipid synthesis. Because membrane lipids travel by fast axoplasmic transport, there would seem less need for axonal synthesis of lipids than for cytoskeletal proteins, which are transported much more slowly. On the contrary, at least $50 \%$ of the phosphatidylcholine is synthesized in distal axons of rat sympathetic neurons grown in compartmented cultures (Posse de Chaves et al., 1995). Moreover, block of axonal phosphatidylcholine synthesis inhibited axon growth, whereas blocking synthesis in the cell bodies had no effect (Posse de Chaves et al., 1995). Therefore, the dependence of axon growth on axonal phosphatidylcholine synthesis, but not on protein synthesis, likely reflects the distribution 


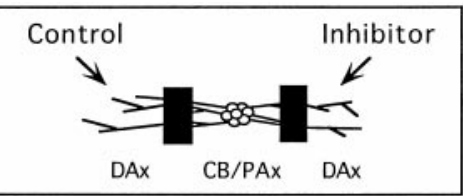

\section{A}

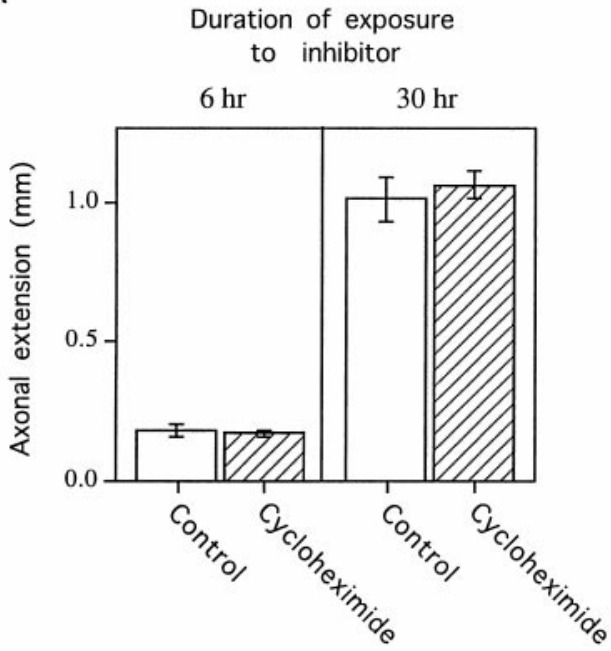

B

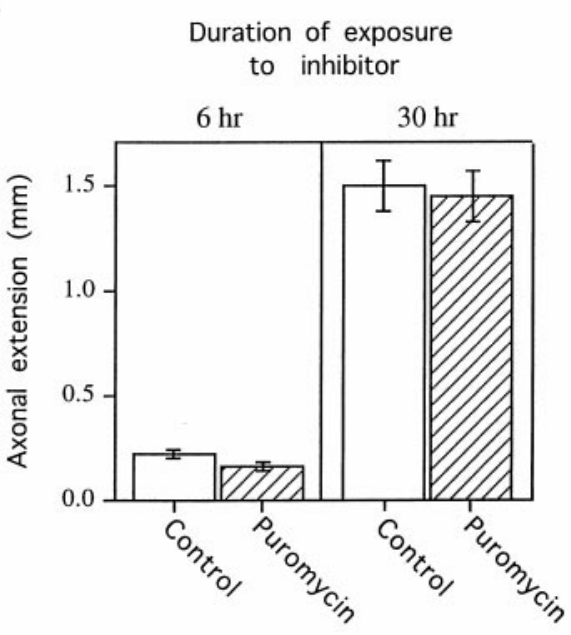

Figure 6. Effect of protein synthesis inhibitors on axonal growth. Cycloheximide $(100 \mu \mathrm{g} / \mathrm{ml} ; A)$ or puromycin $(120 \mu \mathrm{g} / \mathrm{ml} ; B)$ was applied directly to axons in the right compartments of intact cultures, and medium without inhibitor was applied to axons in the left compartments as control. The growth of axons after introduction of the inhibitors was measured after 6 and $30 \mathrm{hr}$ as described in Materials and Methods. The mean \pm SE axonal extension for each time point is shown; $n=15-34$ tracks.

and organization of the synthetic machinery within the neuron rather than limitations imposed by axonal transport.

At this stage, we can only speculate about the biological significance of our observations. Electron microscopic observations of cultured rat sympathetic neurons indicate that dendrites extend only short distances from the cell bodies (Landis, 1976), which would exclude them from crossing into the distal compartments. Only axons can reach the distal compartments. In culture, sympathetic axons possess growth cones and have been shown to possess neurotransmitter release sites (Landis, 1978). Our present results show that these axons growing in culture can synthesize small quantities of actin, $\beta$-tubulin, and other proteins at sites 1 $\mathrm{mm}$ or more away from the cell body. Our present data do not reveal whether protein synthesis is confined to a specific region of the axon, nor do they reveal whether axonal protein synthesis in vivo occurs during axonal growth, collateral sprouting, axonal regeneration, or in mature axons that no longer possess growth cones.

Tobias and Koenig (1975a,b) have shown the rate of axonal protein synthesis after axonal injury increases in the proximal stump. Therefore, we speculate that after nerve injury, the level of axonal protein synthesis we observe may significantly increase in regenerating and sprouting axons. In addition, axonal protein synthesis may perform a maintenance function under normal conditions. At the axoplasmic transport velocity of $4 \mathrm{~mm} / \mathrm{d}$ for tubulin (Campenot et al., 1996), several months would be required for cytoskeletal proteins synthesized in cell bodies to reach the most distal axons in the extremities of an adult human. During this time, much of these proteins may be lost by normal protein turnover. Koenig (1991) has suggested that protein production by axons may compensate for the losses caused by trans- port in long axons. Although the question remains open, our results are consistent with this possibility.

Regardless of the exact circumstances of expression of axonal protein synthesis in vivo, our results clearly demonstrate that there is no inherent obstacle preventing axons from synthesizing proteins at sites distant from the cell body. Moreover, the specific axonal synthesis of cytoskeletal proteins suggests that there are biologically significant exceptions to the long-standing belief that proteins cannot be synthesized in axons.

\section{REFERENCES}

Bassell GJ, Zhang H, Byrd AL, Femino AM, Singer RH, Taneja KL, Lifshitz LM, Herman IM, Kosik KS (1998) Sorting of $\beta$-actin mRNA and protein to neurites and growth cones in culture. J Neurosci 18:251-265.

Campenot RB (1977) Local control of neurite development by nerve growth factor. Proc Natl Acad Sci USA 74:4516-4519.

Campenot RB (1982) Development of sympathetic neurons in compartmentalized cultures. I. Local control of neurite growth by nerve growth factor. Dev Biol 93:1-12.

Campenot RB (1992) Compartmented culture analysis of nerve growth. In: Cell-cell interactions: a practical approach (Stevenson B, Paul D, Gallin W, eds), pp 275-298. Oxford: IRL.

Campenot RB (1997) Construction and use of compartmented cultures. In: Protocols for neural cell culture, Ed 2 (Federoff S, Richardson A, eds) pp 107-116. Totowa, NJ: Humana.

Campenot RB, Lund K, Senger DL (1996) Delivery of newly synthesized tubulin to rapidly growing distal axons of sympathetic neurons in compartmented cultures. J Cell Biol 135:701-709.

Capano CP, Giuditta A, Castigli E, Kaplan BB (1987) Occurrence and sequence complexity of polyadenylated RNA in squid axoplasm. J Neurochem 49:698-704.

Chun JT, Gioio AE, Crispino M, Giuditta A, Kaplan BB (1995) Characterization of squid enolase mRNA: sequence analysis, tissue distribution, and axonal localization. Neurochem Res 20:923-930. 
Chun JT, Gioio AE, Crispino M, Eyman M, Giuditta A, Kaplan BB (1997) Molecular cloning and characterization of a novel mRNA present in the squid giant axon. J Neurosci Res 49:144-153.

Crispino M, Capano CP, Kaplan BB, Giuditta A (1993) Neurofilament proteins are synthesized in nerve endings from squid brain. J Neurochem 61:1144-1146.

Davis L, Dou P, DeWit M, Kater SB (1992) Protein synthesis within neuronal growth cones. J Neurosci 12:4867-4877.

Gioio AE, Chun JT, Crispino M, Capano CP, Giuditta A, Kaplan BB (1994) Kinesin mRNA is present in the squid giant axon. J Neurochem 63:13-18.

Giuditta A, Cupello A, Lazzarini G (1980) Ribosomal RNA in the axoplasm of the squid giant axon. J Neurochem 34:1757-1760.

Giuditta A, Menichini E, Perrone Capano C, Langella M, Martin R, Castigli E, Kaplan BB (1991) Active polysomes in the axoplasm of the squid giant axon. J Neurosci Res 28:18-28.

Hollenbeck PJ, Bray D (1987) Rapidly transported organelles containing membrane and cytoskeletal components: their relation to axonal growth. J Cell Biol 105:2827-2835.

Kaplan BB, Gioio AE, Perrone Capano C, Crispino M, Giuditta A (1992) $\beta$-Actin and $\beta$-tubulin are components of a heterogeneous mRNA population present in the squid giant axon. Mol Cell Neurosci 3:133-144.

Koenig E (1979) Ribosomal RNA in Mauthner axon: implications for a protein synthesizing machinery in the myelinated axon. Brain Res 174:95-107.

Koenig E (1989) Cycloheximide-sensitive $\left[{ }^{35}\right.$ S $]$ methionine labeling of proteins in goldfish retinal ganglion cell axons in vitro. Brain Res 481:119-123.

Koenig E (1991) Evaluation of local synthesis of axonal proteins in the goldfish Mauthner cell axon and axons of dorsal and ventral roots of the rat in vitro. Mol Cell Neurosci 2:384-394.

Koenig E, Adams P (1982) Local protein synthesizing activity in axonal fields regenerating in vitro. J Neurochem 39:386-400.

Koenig E, Martin R (1996) Cortical plaque-like structures identify ribosome-containing domains in the Mauthner cell axon. J Neurosci 16:1400-1411.
Koenig E, Kinsman S, Repasky E, Sultz L (1985) Rapid mobility of motile varicosities and inclusions containing alpha-spectrin, actin, and calmodulin in regenerating axons in vitro. J Neurosci 5: 715-729.

Landis SC (1976) Rat sympathetic neurons and heart myocytes developing in microcultures. Correlation of the fine structure of the endings with neurotransmitter function in single neurons. Proc Natl Acad Sci USA 73:4220-4224.

Landis SC (1978) Growth cones of cultured sympathetic neurons contain adrenergic vesicles. J Cell Biol 78:R8-R14.

Lasek RJ, Dabrowski C, Nordlander R (1973) Analysis of axoplasmic RNA from invertebrate giant axons. Nat New Biol 244:162-165.

Litman P, Barg J, Rindzoonski L, Ginzburg I (1993) Subcellular localization of Tau-messenger RNA in differentiating neuronal cell culture-implications for neuronal polarity. Neuron 10:627-638.

Mohr E, Fehr S, Richter D (1991) Axonal transport of neuropeptide encoding mRNAs within the hypothalamo-hypophyseal tract of rats. EMBO J 10:2419-2424.

Olink-Coux M, Hollenbeck PJ (1996) Localization and active transport of mRNA in axons of sympathetic neurons in culture. J Neurosci 16:1346-1358.

Posse de Chaves E, Vance DE, Campenot RB, Vance JE (1995) Axonal synthesis of phosphatidylcholine is required for normal axonal growth in rat sympathetic neurons. J Cell Biol 128:913-918.

Tobias GS, Koenig E (1975a) Axonal protein synthesizing activity during the early outgrowth period following neurotomy. Exp Neurol 49:221-234.

Tobias GS, Koenig E (1975b) Influence of nerve cell body and neurolemma cell on local axonal protein synthesis following neurotomy. Exp Neurol 49:235-245.

Vance JE, Pan D, Vance DE, Campenot RB (1991) Biosynthesis of membrane lipids in rat axons. J Cell Biol 115:1061-1068.

Weiner OD, Zorn AM, Krieg PA, Bittner GD (1996) Medium weight neurofilament mRNA in goldfish Mauthner axoplasm. Neurosci Lett 213:83-86. 